\title{
Effect of Varying Dietary Crude Protein Level on Feed Intake, Nutrient Digestibility, Milk Production, and Nitrogen Use Efficiency by Lactating Holstein-Friesian Cows
}

\author{
Constantine Bakyusa Katongole * and Tianhai Yan \\ Sustainable Agri-Food Sciences Division, Agri-Food and Biosciences Institute, Large Park, Hillsborough, \\ County Down, Northern Ireland BT26 6DR, UK; Tianhai.Yan@afbini.gov.uk \\ * Correspondence: Constantine.Katongole@afbini.gov.uk
}

Received: 12 November 2020; Accepted: 17 December 2020; Published: 19 December 2020

check for updates

Simple Summary: Over the past decades, European Union countries have been under increasing pressure to reduce nitrogen pollution resulting from agricultural activities and ensure compliance with environmental legislations aimed at reducing the amount of nitrogen emitted into the atmosphere. Among the various forms of nitrogen losses into the atmosphere from agriculture, losses associated with farmed livestock (particularly dairy cows) are top priority. The nitrogen losses associated with livestock originate mostly from the excreta (feces and urine), with dietary protein content as a major driver. Despite the concern about dietary protein, the feeding of diets with excess protein relative to requirements (protein overfeeding) is evident on many commercial dairy farms in Europe, with the belief that it enhances milk production and in part for purposes of providing a margin of safety.

\begin{abstract}
The effect of dietary crude protein (CP) level on intake, digestibility, milk production, and nitrogen $(\mathrm{N})$ use efficiency was studied. Twenty-four Holstein-Friesian cows (17 multiparous and seven primiparous) were grouped by parity, days in milk, milk yield, and live weight into six blocks of four, and randomly assigned to four total mixed ration (TMR) treatments, containing 141, 151,177 , or $210 \mathrm{~g} \mathrm{CP} / \mathrm{kg}$ dry matter (DM), over 28 day experimental periods. Apparent total-tract DM and fiber digestibilities and milk fat composition were similar across treatments. Milk protein and urea-N compositions, and urinary and manure $\mathrm{N}$ excretion increased linearly, while milk $\mathrm{N}$ efficiency (MNE) decreased linearly with increasing CP. DM intake was highest with the 177 diet, while CP intake increased linearly with increasing CP, peaking at $200 \mathrm{~g} / \mathrm{kg}$ DM. Milk yield increased with CP intake for the three lower $\mathrm{CP}$ levels, peaking at $176 \mathrm{~g} \mathrm{CP} / \mathrm{kg} \mathrm{DM}$. The further increase in $\mathrm{CP}$ level from 177 to $210 \mathrm{~g} / \mathrm{kg}$ DM did not result in improved milk yield, but resulted in decreased milk $\mathrm{N}$ secretion and increased urinary $\mathrm{N}$ excretion. In summary, milk protein composition increased linearly with increasing $\mathrm{CP}$, accompanied by a linear decrease in MNE, resulting in a bell-shaped relationship between milk yield and dietary $\mathrm{CP}$ level.
\end{abstract}

Keywords: dietary crude protein; milk yield; milk $\mathrm{N}$ efficiency; total mixed ration

\section{Introduction}

Maximizing milk production while minimizing protein input has been one of the extremely important tasks in dairy cow nutrition in recent years. Firstly, protein is a considerably expensive nutrient; hence, feeding excess protein relative to requirements (i.e., protein overfeeding) results in unnecessary feeding expenses and, hence, low dairy farm profitability. Protein overfeeding can also result in low dairy farm profitability because of reduced milk nitrogen $(\mathrm{N})$ efficiency [1]. As the 
dietary protein level increases beyond that needed to meet requirements, feed $\mathrm{N}$ use efficiency reduces, whereby milk $\mathrm{N}$ secretion reduces and the excretion of urinary $\mathrm{N}$ increases [2,3]. Secondly, dietary protein is one of the major drivers of environmental pollution with $\mathrm{N}$ from dairy farming [3-5]. Arriaga [6] reported that only $25.8 \%$ (range $19.2 \%$ to $32.3 \%$ ) of the total feed $\mathrm{N}$ consumed by cows on commercial dairy farms is secreted in milk, with the majority of the remainder being excreted about equally in feces and urine. Powell [7] reported an average of $25.4 \%$ (range $18.2 \%$ to $32.6 \%$ ). In spite of these environmental and economic concerns, protein overfeeding is rather a common occurrence under modern dairy production, particularly on farms feeding total mixed rations [6,8]. In addition to the inaccuracies associated with some protein models for balancing protein requirements of lactating dairy cows, the tendency on the part of dairy farmers to feed higher crude protein $(\mathrm{CP})$ diets than recommended has been mentioned to potentially lead to protein overfeeding [8].

Over the past two decades, considerable research efforts have been directed at reducing $\mathrm{N}$ pollution from livestock production in response to increased environmental concerns and legislations regarding emissions from agriculture. Livestock excreta (urine and feces) can contribute to $\mathrm{N}$ pollution of the environment as ammonia and nitrous oxide (through volatilization, nitrification, and denitrification processes), nitrate leached to ground water, and $\mathrm{N}$ runoff to surface water [9-11]. Various studies have assessed the effect of dietary $\mathrm{CP}$ level on $\mathrm{N}$ use efficiency and reported a nearly twofold increase in urinary $\mathrm{N}$ excretion when dietary CP contents were increased from $15.1 \%$ to $18.4 \%$ [1], $16.2 \%$ to $20.1 \%$ [12], $14.8 \%$ to $16.7 \%$ [13], and $14.9 \%$ to $17.5 \%$ [14]. Thus, reducing dietary protein content should decrease excretion of the environmentally labile urinary N. However, the strategy of reducing dietary protein content is only viable if milk production remains economically profitable. Furthermore, substantial evidence has revealed that dietary $\mathrm{N}$ use efficiency (consequently, the extent of $\mathrm{N}$ excretion in urine and feces) by dairy cows at a given level of $\mathrm{N}$ intake is influenced by a number of factors, including animal variation (i.e., genetic variability for digestive or metabolic efficiency). Thus, the present study assessed $\mathrm{N}$ utilization and excretion using Northern Irish dairy cows. This study evaluated the effect of feeding total mixed ration (TMR) diets containing varying levels of CP on feed intake, nutrient digestibility, milk production, and $\mathrm{N}$ use efficiency by lactating Holstein-Friesian cows.

\section{Materials and Methods}

This study was conducted at the Agri-Food and Biosciences Institute, Hillsborough (Northern Ireland, UK). The study was approved by the Ethical Review Committee of the Institute and was in accordance with the Animals (Scientific Procedures) Act 1986.

\subsection{Experimental Animals}

Twenty-four lactating Holstein-Friesian cows (17 multiparous and seven primiparous) were selected from the autumn-calving dairy herd at Agri-Food and Biosciences Institute, Hillsborough, UK. The cows were between 146 and 200 days in milk (DIM), averaging 2.4 parity (standard deviation (SD) 1.5), $645 \mathrm{~kg}$ live weight (SD 57), and $32 \mathrm{~kg}$ of milk/day (SD 6) at the time of enrolment in the study.

\subsection{Treatment Diets and Experimental Design}

The study involved four total mixed ration (TMR) treatment diets that were prepared from perennial ryegrass (Lolium perenne L.) silage and two concentrate meals (i.e., low protein and high protein). The two concentrate meals were supplied premixed containing 123 and $220 \mathrm{~g} \mathrm{CP} / \mathrm{kg}$ (fresh basis) for the low- and high-protein concentrate meals, respectively. The chemical compositions of the ryegrass silage and the two concentrate meals that were used to make the TMR treatment diets are presented in Table 1. The silage and concentrate were mixed in a ratio of about 48:52 (dry matter (DM) basis) targeting dietary CP levels of $141,151,177$, or $210 \mathrm{~g} / \mathrm{kg} \mathrm{DM}$. The chemical compositions of the TMR treatment diets are presented in Table 2. 
The 24 cows were grouped into six blocks of four cows on the basis of parity, days in milk, pretreatment milk yield, live weight, and body condition score. The cows within each block were randomly allocated to one of the four TMR treatment diets. Thereafter, the 24 cows were randomly paired up (i.e., 12 cow-pairs) ensuring that no cow-pair consisted of cows allocated to the same treatment diet (Figure 1). Two cows (i.e., one cow-pair) were enrolled in the study at a time (in the order from pair 1 to pair 12, at 3 day intervals) for 28 day experimental periods. The first 20 days were for adaptation to the treatment diets, followed by 5 days of individual feeding (for collecting nutrient balance data), and finally 3 days in two respiration chambers for measuring gas emissions. It is important to point out that, in addition to nutrient balance assessment, this study had an additional objective of measuring gas emissions using two respiration chambers. It was for this reason that the study was designed to enroll the experimental cows in pairs (results of the gas emissions objective are not included here).

Table 1. Chemical composition of the silage and concentrates used. DM, dry matter; $\mathrm{CP}$, crude protein; NDF, neutral detergent fiber; ADF, acid detergent fiber.

\begin{tabular}{|c|c|c|c|}
\hline & \multirow[b]{2}{*}{ Ryegrass Silage } & \multicolumn{2}{|c|}{ Concentrate } \\
\hline & & Low Protein & High Protein \\
\hline \multicolumn{4}{|l|}{ Ingredient, \% DM } \\
\hline Wheat & & 24.5 & 22.0 \\
\hline Barley & & 23.5 & 21.9 \\
\hline Sugar beet pulp & & 20.2 & 2.0 \\
\hline Maize gluten & & 12.5 & 4.0 \\
\hline Soya bean hulls & & 8.1 & 7.6 \\
\hline Calcium salts of palm fatty acid & & 2.7 & 1.6 \\
\hline Rapeseed meal & & 2.0 & 10.2 \\
\hline Soya bean meal feed dehulled & & 2.0 & 26.3 \\
\hline Calcium carbonate & & 1.4 & 1.4 \\
\hline Acid Buf ${ }^{1}$ & & 1.4 & 1.4 \\
\hline Sodium chloride & & 0.7 & 0.7 \\
\hline Super dairy $^{2}$ & & 0.5 & 0.5 \\
\hline Magnesium oxide & & 0.3 & 0.3 \\
\hline ActiSaf $^{3}$ & & 0.1 & 0.1 \\
\hline \multicolumn{4}{|l|}{ Chemical composition } \\
\hline $\mathrm{DM}, \mathrm{g} / \mathrm{kg}$ & $336 \pm 19.3$ & $906 \pm 5.2$ & $903 \pm 2.8$ \\
\hline $\mathrm{CP}, \mathrm{g} / \mathrm{kg} \mathrm{DM}$ & $154 \pm 8.9$ & $134 \pm 2.9$ & $252 \pm 1.5$ \\
\hline Rumen-degraded protein (RDP) ${ }^{4}, \mathrm{~g} / \mathrm{kg} \mathrm{CP}$ & 765 & 688 & 693 \\
\hline Rumen-undegraded protein (RUP) ${ }^{4}, \mathrm{~g} / \mathrm{kg} \mathrm{CP}$ & 235 & 312 & 307 \\
\hline NDF, $\mathrm{g} / \mathrm{kg}$ DM & $554 \pm 16.7$ & $283 \pm 10.5$ & $243 \pm 5.7$ \\
\hline $\mathrm{ADF}, \mathrm{g} / \mathrm{kg} \mathrm{DM}$ & $314 \pm 12.9$ & $134 \pm 3.6$ & $106 \pm 10.6$ \\
\hline Water-soluble carbohydrates (WSC), g/kg DM & $104 \pm 1.1$ & $55 \pm 5.9$ & $79 \pm 1.9$ \\
\hline Ash, $\mathrm{g} / \mathrm{kg} \mathrm{DM}$ & $81 \pm 4.6$ & $75 \pm 4.2$ & $81 \pm 3.9$ \\
\hline $\mathrm{pH}$ & 4.6 & - & - \\
\hline Total ammonia $\mathrm{N}, \%$ total $\mathrm{N}$ & 6.6 & - & - \\
\hline Lactic acid, \%DM & 12.2 & - & - \\
\hline Acetic acid, \%DM & 3.8 & - & - \\
\hline Butyric acid, \%DM & 0.57 & - & - \\
\hline
\end{tabular}

\footnotetext{
${ }^{1}$ Calcified seaweed included as a rumen acidity buffer (AB Vista, Belfast, UK); ${ }^{2}$ mineral and vitamin premix pack for dairy cows (Devenish Nutrition, Belfast, UK), containing: vitamin A (9000 IU/kg), vitamin D3 (2000 IU/kg), vitamin E as alpha-tocopherol $(75 \mathrm{mg} / \mathrm{kg})$, biotin $(20 \mathrm{mg} / \mathrm{kg})$, iodine $7.5 \mathrm{mg} / \mathrm{kg}(11.90 \mathrm{mg} / \mathrm{kg}$ calcium iodate), cobalt $0.16 \mathrm{mg} / \mathrm{kg}$ $(3.2 \mathrm{mg} / \mathrm{kg}$ granulated cobalt carbonate), copper $40 \mathrm{mg} / \mathrm{kg}(120 \mathrm{mg} / \mathrm{kg}$ cupric sulfate pentahydrate, $100 \mathrm{mg} / \mathrm{kg}$ cupric chelate of amino acid hydrate), manganese $50 \mathrm{mg} / \mathrm{kg}$ (64 mg/kg manganous oxide), zinc $100 \mathrm{mg} / \mathrm{kg}$ (104.175 mg/kg zinc oxide, $166.67 \mathrm{mg} / \mathrm{kg}$ zinc chelate of protein hydrolysates), and selenium $0.7 \mathrm{mg} / \mathrm{kg}$ ( $50 \mathrm{mg} / \mathrm{kg}$ selenium yeast); ${ }^{3}$ live yeast Sc47 (Saccharomyces cerevisiae) for rumen health (Phileo, Belfast, UK); ${ }^{4}$ feed into milk (FiM) system according to Thomas [15].
} 
Table 2. Ingredients and chemical composition of the total mixed ration (TMR) diets.

\begin{tabular}{ccccc}
\hline & \multicolumn{4}{c}{ Dietary CP Content, g/kg DM } \\
\cline { 2 - 5 } & $\mathbf{1 4 1}$ & $\mathbf{1 5 1}$ & $\mathbf{1 7 7}$ & $\mathbf{2 0 1}$ \\
\hline Ingredient, \% of TMR DM & & & & \\
Ryegrass silage & 47.3 & 47.9 & 47.7 & 47.5 \\
Low protein concentrate & 52.7 & 43.0 & 22.0 & 3.0 \\
High protein concentrate & 0.0 & 9.1 & 30.3 & 49.5 \\
Chemical composition $^{1}$ & & & & \\
DM, g/kg & 507 & 513 & 510 & 508 \\
CP, g/kg DM & 141 & 151 & 177 & 201 \\
RDP, g/kg CP & 103 & 109 & 127 & 144 \\
RUP, g/kg CP & 39 & 41 & 49 & 56 \\
NDF, g/kg DM & 411 & 408 & 399 & 388 \\
ADF, g/kg DM & 218 & 218 & 214 & 209 \\
WSC, g/kg DM & 81 & 82 & 86 & 90 \\
Ash, g/kg DM & 78 & 78 & 80 & 81 \\
\hline
\end{tabular}

${ }^{1}$ Calculated as formulated from the analyzed chemical compositions of the individual ingredients.

\begin{tabular}{|ccccc|}
\hline Block 1 & \multicolumn{4}{c|}{ Cow } \\
\cline { 2 - 5 } Diet & 1 & 2 & 3 & 4 \\
\hline 141 & Pair 1 & Pair 1 & & \\
151 & & Pair 5 & \\
177 & & & & Pair 7 \\
201 & & & & \\
\hline
\end{tabular}

\begin{tabular}{|ccccc|}
\hline Block 2 & \multicolumn{5}{c|}{ Cow } \\
\cline { 2 - 5 } Diet & 5 & 6 & 7 & 8 \\
\hline 141 & Pair 8 & & & \\
151 & & Pair 12 & & \\
177 & & & Pair 7 & \\
201 & & & & Pair 9 \\
\hline
\end{tabular}

\begin{tabular}{|ccccc|}
\hline Block 3 & \multicolumn{5}{c|}{ Cow } \\
\cline { 2 - 5 } Diet & 9 & 10 & 11 & 12 \\
\hline 141 & Pair 6 & & \\
151 & & Pair 5 & & \\
177 & & & Pair 12 & \\
201 & & & & Pair 11 \\
\hline
\end{tabular}

\begin{tabular}{|rcccc|}
\hline Block 4 & \multicolumn{4}{c|}{ Cow } \\
\cline { 2 - 5 } Diet & 13 & 14 & 15 & 16 \\
\hline 141 & Pair 3 & & & \\
151 & & Pair 8 & Pair 10 \\
177 & & & & Pair 2 \\
201 & & & & \\
\hline
\end{tabular}

\begin{tabular}{|ccccc|}
\hline Block 5 & \multicolumn{5}{c|}{ Cow } \\
\cline { 2 - 5 } Diet & 17 & 18 & 19 & 20 \\
\hline 141 & Pair 11 & & \\
151 & & Pair 9 & \\
177 & & & Pair 3 & \\
201 & & & & Pair 6 \\
\hline
\end{tabular}

\begin{tabular}{|ccccc|}
\hline Block 6 & \multicolumn{4}{c|}{ Cow } \\
\cline { 2 - 5 } Diet & 21 & 22 & 23 & 24 \\
\hline 141 & Pair 10 & & \\
151 & & Pair 4 & \\
177 & & & Pair 2 & \\
201 & & & & Pair 4 \\
\hline
\end{tabular}

Figure 1. Layout for the six blocks of four cows each (including how they were paired up) and four treatment diets. Pair numbers also refer to the order in which the cows were enrolled in the study. Two cows (i.e., one pair) were enrolled at a time in the order from pair 1 to pair 12, at 3 day intervals.

\subsection{Feeding Management and Measurements}

During the 20 day adaptation period, the cows were group-fed their TMR treatment diets. The decision to group-feed the cows was because of the lack of personnel (required for the daily management of individual animals) and there were not enough individual tie-stalls to house that number of cows. The respective TMR diets were mixed separately (for each treatment) using a feeder wagon (Vari-Cut 12, Redrock, Armagh, Northern Ireland), and tipped into a series of feeders mounted on weigh scales. Individual cow access to the feeders was programmed (cows were able to only access feeders containing their rightful treatment diets) by means of an electronic "neck-tag" identification 
system (Controlling and Recording Feed Intake (CRFI), BioControl, Rakkestad, Norway). This made it possible to monitor the individual cow intakes on a daily basis. During the 5 day individual feeding period, the cows were housed in individual tie-stalls with continuous access to fresh water. The head of each cow was loosely tied at a halter in the individual tie-stall. The respective TMR diets were mixed separately (for each cow) using a power concrete mixer. The cows were fed once daily at 9:00 a.m., and then any refusals (orts) and spilled feed were collected and weighed on the following day at about 8:00 a.m. (before new feed was offered). The amount of TMR offered was adjusted daily on the basis of the previous day's intake to ensure $10 \%$ orts.

Day 1 of the 5 day individual feeding periods was for adaptation, and the final 4 days were for data collection (milk yield, feed intake, and total feces and urine). The daily TMR intakes were manually recorded. The cows were milked twice daily (a.m. and p.m.) using the milking apparatus installed in the tie-stalls, and the individual milk yields were recorded manually. The milk yields were adjusted to $4 \%$ fat-corrected milk (4\% FCM). Daily a.m. and p.m. milk samples were collected and preserved with an antimicrobial preservative (Broad Spectrum Microtabs ${ }^{\mathrm{TM}}$ II: Advanced Instruments Inc., USA) in a refrigerator (at $5{ }^{\circ} \mathrm{C}$ ). At the end of each 5 day individual feeding period, the a.m. and p.m. milk samples were bulked, and a composite sample was analyzed for protein, fat, lactose, casein, and urea-N compositions using an infrared milk analyzer MilkoScan Combifoss ${ }^{\mathrm{TM}} 7$; Foss Electric, Hillerød, Denmark).

For the $24 \mathrm{~h}$ total collections of feces and urine, a Velcro patch (vinyl fabric, about $15 \mathrm{~cm} \times 15 \mathrm{~cm}$ ) was designed with a hole to correspond to the vulva opening. The patch was glued (EVO-STIK 528 Instant Contact Adhesive: Bostik Ltd., Stafford, UK) to each cow around the perineal region (area under the tail) to facilitate collection of urine separately from feces. The Velcro patches were supported by two straps (one on either side) that were glued to the rump. For each patch, Velcro tape (loop-side) was sewn around the hole corresponding to the vulva, which helped to hold in position a urine collection unit (with hook-side Velcro tape) connected to an $80 \mathrm{~mm}$ polyvinyl chloride (PVC) Layflat Hose (for channeling the urine into a plastic collection container). The feces of each cow were collected in a large plastic collection tray that was placed behind each tie-stall. To prevent ammonia from volatilizing, urine was collected after adding approximately $300 \mathrm{~mL}$ of $50 \%$ sulfuric acid to each urine collection container daily. The total daily amounts of feces and urine produced by each cow ( $24 \mathrm{~h}$ total) were weighed daily at 8:00 a.m. and recorded. About $2 \%$ of the day's feces and $500 \mathrm{~mL}$ of the day's urine were sampled daily and stored in a refrigerator $\left(\right.$ at $\left.5{ }^{\circ} \mathrm{C}\right)$ for subsequent analysis. At the end of each 5 day individual feeding period, the daily fresh fecal samples of each cow were bulked (on an equal weight basis) and thoroughly mixed into a composite sample of about $1 \mathrm{~kg}$. For each cow, a subsample of about $100 \mathrm{~g}$ was analyzed for total $\mathrm{N}$ content using wet chemistry analysis. The rest of the fresh sample was oven-dried at $60^{\circ} \mathrm{C}$ for $144 \mathrm{~h}$ for DM content determination. The fecal DM content was then used to calculate the total daily fecal DM output for each cow. The oven-dried fecal samples were ground through a $1 \mathrm{~mm}$ sieve and analyzed for neutral detergent fiber (NDF) and acid detergent fiber (ADF) [16], as well as ash concentrations.

Two samples (about $200 \mathrm{~g}$ each) of the ryegrass silage and one sample (about $200 \mathrm{~g}$ ) of the concentrate meals used were taken daily. One of the two silage samples and the concentrate meal samples were oven-dried at $60{ }^{\circ} \mathrm{C}$ for $48 \mathrm{~h}$ for DM content determination. The DM content (silage and concentrate meals) was used to calculate the total daily DM intake of each cow (from the daily TMR intakes). The other silage sample was stored fresh in a refrigerator $\left(\right.$ at $\left.5{ }^{\circ} \mathrm{C}\right)$. At the end of each 5 day individual feeding period, the daily oven-dried samples were ground through a $1 \mathrm{~mm}$ sieve, bulked (on an equal weight basis), and the composite samples were analyzed for total N, NDF, ADF, and ash content. Similarly, the daily fresh silage samples were bulked (on an equal weight basis), and composite samples were analyzed for total $\mathrm{N}, \mathrm{pH}$, ammonia-N, and volatile fatty acid concentration using wet chemistry analysis. The DM content and analyzed chemical compositions of the silage and the two concentrate meals were used to calculate the chemical compositions of the TMR diets (Table 2). 


\subsection{Statistical Analysis}

All data were analyzed using SAS (version 9.1, SAS Institute, Cary, NC, USA, 2003). Treatment differences were considered significant when $p \leq 0.05$ and tendencies when $0.05<p \leq 0.10$. The effect of dietary $\mathrm{CP}$ level on feed intake, nutrient digestibility, milk production, and nitrogen use efficiency was analyzed using the PROC MIXED procedure for repeated measures. The repeated measure was day, and the variable that uniquely defined the subjects was cow within order of enrolment in the study (cow-pair). A first-order autoregressive covariance structure was used, while the residual maximum likelihood (REML) was used as the estimation method. The statistical model included block, diet, day, and diet $\times$ day interaction as fixed effects. No covariate was included in the statistical model for the feed intake, milk components (fat, lactose, protein, casein, and urea-N) yield, and excreta $\mathrm{N}$ data. Pretreatment milk yield was included as a covariate for the milk yield and milk $\mathrm{N}$ secretion data, while pretreatment milk yield, DIM, and parity were included as covariates for the apparent total-tract digestibility data. Polynomial contrasts were used to detect linear and quadratic effects of dietary CP level. Selection of the fixed and covariate effects depended on whether their inclusion in the model resulted in a smaller Akaike information criterion (AIC) and/or made a meaningful improvement in treatment means and standard errors.

The effect of dietary CP level on milk components was analyzed using the PROC MIXED procedure. Block and diet were included in the statistical model as fixed effects. DIM was included as a covariate. The effect of cow within the order of enrolment in the study (cow-pair) was considered a random factor. Linear and quadratic effects of dietary $\mathrm{CP}$ level were also estimated.

\section{Results and Discussion}

\subsection{Feed Intake and Apparent Total-Tract Digestibility}

Intakes of DM, organic matter (OM), NDF, and ADF were affected by dietary CP level in a quadratic $(p<0.05)$ manner, being higher $(p<0.05)$ with the 177 diet, but not different between the 141, 151, and 201 diets (Table 3). Quadratic functions predicted peak intakes of DM, OM, NDF, and ADF to occur at dietary $\mathrm{CP}$ levels of $176,175,173$, and $173 \mathrm{~g} / \mathrm{kg} \mathrm{DM}$, respectively (an average dietary $\mathrm{CP}$ level of $174 \mathrm{~g} / \mathrm{kg} \mathrm{DM})$. Intake of CP was affected by dietary CP level in a linear $(p<0.05)$ and quadratic $(p<0.05)$ manner. The intake of CP first increased linearly with increasing dietary $\mathrm{CP}$ level to a peak value and then decreased. A quadratic function predicted the peak value to occur at a dietary CP level of $200 \mathrm{~g} / \mathrm{kg}$ DM. As was the case in the current study, Broderick [2] also reported a linear increase in DM intake as dietary CP was increased from $15.1 \%$ to $16.7 \%$ and then to $18.4 \%$. However, in contrast, Mutsvangwa [15] reported no dietary CP level effects on the intakes of DM, OM, NDF, and ADF when lactating cows were fed TMR diets containing either $14.9 \%$ or $17.5 \% \mathrm{CP}$. Olmos Colmenero and Broderick [17] also reported no dietary CP level effect on DM intake when CP levels increased from $13.5 \%$ to $15.0 \%, 16.5 \%, 17.9 \%$, and then to $19.4 \% \mathrm{CP}$.

Apparent total-tract DM, OM, NDF, and ADF digestibilities did not differ $(p>0.05)$ across dietary $\mathrm{CP}$ levels and averaged 714, 734, 606, and $612 \mathrm{~g} / \mathrm{kg}$, respectively (Table 3). This result appears to contradict some previous studies with TMR-fed dairy cows. Olmos Colmenero and Broderick [17] reported quadratic increases in apparent $\mathrm{DM}, \mathrm{NDF}$, and $\mathrm{ADF}$ digestibilities as dietary $\mathrm{CP}$ was increased from $13.5 \%$ to $15.0 \%, 16.5 \%, 17.9 \%$, and then to $19.4 \% \mathrm{CP}$, while Groff and $\mathrm{Wu}$ [18] reported linear and quadratic increases in ADF digestibility as dietary CP was increased from $15.0 \%$ to $16.25 \%$, $17.5 \%$, and then to $18.75 \%$ CP. However, although Broderick [2] reported linear increases in apparent digestibilities of NDF and ADF as dietary CP was increased from $15.1 \%$ to $16.7 \%$ and then to $18.4 \%$, this author observed no dietary $\mathrm{CP}$ level effect on apparent DM digestibility. Unsurprisingly, the apparent total-tract digestibility of $\mathrm{CP}$ increased linearly $(p<0.05)$ with increasing dietary $\mathrm{CP}$ level, being highest with the 201 diet, intermediate with the 177 diet, and lowest with the 141 or 151 diets. Increased dietary protein level results in increased dilution of the metabolic fecal $\mathrm{N}$, thus yielding a greater apparent digestibility of CP [19,20]. Similarly, Broderick [2] also reported a linear increase in N 
digestibility as dietary CP content was increased from $15.1 \%$ to $18.4 \%$, while Olmos Colmenero and Broderick [17] reported linear and quadratic increases in CP digestibility as dietary CP content was increased from $13.5 \%$ to $19.4 \%$.

Table 3. Effect of dietary CP level on intake and apparent total-tract digestibility.

\begin{tabular}{|c|c|c|c|c|c|c|c|c|}
\hline & \multicolumn{4}{|c|}{ Dietary CP Content, g/kg DM } & \multirow{2}{*}{ SEM } & \multicolumn{3}{|c|}{$p$-Value } \\
\hline & 141 & 151 & 177 & 201 & & Diet & Linear & Quadratic \\
\hline \multicolumn{9}{|l|}{ DM intake, $\mathrm{kg} /$ day } \\
\hline Silage & $9.1^{\mathrm{b}}$ & $9.1^{\mathrm{b}}$ & $10.7^{\mathrm{a}}$ & $9.4^{\mathrm{b}}$ & 0.359 & 0.014 & 0.138 & 0.011 \\
\hline Concentrate & $10.1^{\mathrm{b}}$ & $9.9^{b}$ & $11.8^{\mathrm{a}}$ & $10.4^{\mathrm{b}}$ & 0.383 & 0.012 & 0.147 & 0.017 \\
\hline Total & $19.2^{b}$ & $18.9^{b}$ & $22.5^{\mathrm{a}}$ & $19.8^{\mathrm{b}}$ & 0.730 & 0.011 & 0.136 & 0.013 \\
\hline OM intake, $\mathrm{kg} /$ day & $17.7^{\mathrm{b}}$ & $17.4^{\mathrm{b}}$ & $20.7^{\mathrm{a}}$ & $18.2^{b}$ & 0.665 & 0.012 & 0.152 & 0.013 \\
\hline $\mathrm{CP}$ intake, $\mathrm{kg} /$ day & $2.72^{b}$ & $2.86^{\mathrm{b}}$ & $3.98^{\mathrm{a}}$ & $3.95^{\mathrm{a}}$ & 0.132 & $<0.0001$ & $<0.0001$ & 0.015 \\
\hline NDF intake, kg/day & $7.91^{\mathrm{b}}$ & $7.72^{b}$ & $8.98^{\mathrm{a}}$ & $7.68^{b}$ & 0.309 & 0.026 & 0.700 & 0.015 \\
\hline $\mathrm{ADF}$ intake, $\mathrm{kg} /$ day & $4.19^{b}$ & $4.12^{b}$ & $4.83^{\mathrm{a}}$ & $4.15^{b}$ & 0.183 & 0.039 & 0.516 & 0.021 \\
\hline \multicolumn{9}{|l|}{$\begin{array}{l}\text { Apparent total-tract } \\
\text { digestibility }\end{array}$} \\
\hline $\mathrm{DM}, \mathrm{g} / \mathrm{kg}$ & 707 & 719 & 715 & 715 & 13.1 & 0.890 & 0.773 & 0732 \\
\hline $\mathrm{OM}, \mathrm{g} / \mathrm{kg}$ & 728 & 737 & 737 & 734 & 12.6 & 0.922 & 0.778 & 0.624 \\
\hline $\mathrm{CP}, \mathrm{g} / \mathrm{kg}$ & $571^{c}$ & $611^{b, c}$ & $641^{b}$ & $695^{a}$ & 16.8 & 0.0002 & $<0.0001$ & 0.928 \\
\hline NDF, g/kg & 604 & 623 & 607 & 590 & 20.9 & 0.640 & 0.391 & 0.524 \\
\hline $\mathrm{ADF}, \mathrm{g} / \mathrm{kg}$ & 613 & 626 & 618 & 591 & 20.6 & 0.556 & 0.289 & 0.414 \\
\hline
\end{tabular}

SEM, standard error of least square means; OM, organic matter; ${ }^{a, b, c}$ least square means in the same row with different superscript letters differ $(p<0.05)$.

\subsection{Milk Yield, Components and Milk Components Yield}

Milk yield was affected by dietary CP level in a quadratic $(p<0.05)$ manner, with no further increase from 177 to $201 \mathrm{~g} \mathrm{CP} / \mathrm{kg}$ DM (Table 4). A quadratic function predicted peak milk yield to occur at a dietary CP level of $176 \mathrm{~g} / \mathrm{kg} \mathrm{DM}$. There was a tendency for higher $(p=0.094) 4 \%$ FCM yield with the 177 diet, showing a trend $(p=0.079)$ toward a quadratic response to increasing dietary $\mathrm{CP}$ level. A quadratic function predicted peak 4\% FCM yield to occur at a dietary CP level of $177 \mathrm{~g} / \mathrm{kg}$ DM. Feed efficiency, expressed as either milk yield or $4 \%$ FCM per $\mathrm{kg}$ of feed DM consumed, was not affected by dietary CP level $(p>0.05)$ and averaged 1.28 and 1.40 , respectively. The lack of dietary CP level effect on feed efficiency suggested that the higher milk yield observed with the 177 diet was at least partially attributable to its higher DM intake.

In the present study, increasing the dietary $\mathrm{CP}$ level beyond $177 \mathrm{~g} \mathrm{CP} / \mathrm{kg} \mathrm{DM}$ did not result in improved milk yield. This result is in agreement with studies by Burgos [21] and Borucki Castro [13], who reported decreases in milk yield when dietary CP increased from $17 \%$ to $21 \%$ and from $19.7 \%$ to $20.1 \%$, respectively. This lack of benefits for milk yield observed in the present study when the dietary $\mathrm{CP}$ was increased beyond $177 \mathrm{~g} / \mathrm{kg}$ DM could be explained by the less efficient ability to salvage and recycle urea- $\mathrm{N}$ to the rumen when ruminants are fed excessively high-protein diets. Urea- $\mathrm{N}$ that is recycled to the rumen acts as a precursor- $\mathrm{N}$ for microbial protein synthesis for subsequent digestion and absorption across the small intestine $[22,23]$. Several studies $[15,24,25]$ have indicated that total urea-N salvaged and recycled to the rumen decreases as dietary protein level increases. Characteristically, high dietary $\mathrm{CP}$ levels result in increased ruminal ammonia- $\mathrm{N}$ concentration $[23,24]$, which has been reported to be inversely related to urea- $\mathrm{N}$ transfer to the rumen $[15,26]$. Thus, increasing the dietary $\mathrm{CP}$ level beyond $177 \mathrm{~g} / \mathrm{kg}$ DM obviously resulted in increased ruminal ammonia-N concentration, which ended up being excreted in urine rather than being salvaged and reutilized. 
Table 4. Effect of dietary CP level on milk yield, components, and milk components yield.

\begin{tabular}{|c|c|c|c|c|c|c|c|c|}
\hline & \multicolumn{4}{|c|}{ Dietary CP Content, g/kg DM } & \multirow{2}{*}{ SEM } & \multicolumn{3}{|c|}{$p$-Value } \\
\hline & 141 & 151 & 177 & 201 & & Diet & Linear & Quadratic \\
\hline \multicolumn{9}{|l|}{ Milk yield } \\
\hline Milk, kg/day & $23.7^{\mathrm{b}}$ & $24.5^{b}$ & $28.6^{\mathrm{a}}$ & $25.3^{\mathrm{a}, \mathrm{b}}$ & 1.29 & 0.048 & 0.153 & 0.044 \\
\hline $4 \%$ FCM, kg/day & 25.6 & 26.6 & 31.1 & 28.1 & 1.56 & 0.094 & 0.114 & 0.079 \\
\hline Milk/DIM & 1.27 & 1.29 & 1.28 & 1.28 & 0.072 & 0.997 & 0.969 & 0.868 \\
\hline $\begin{array}{l}\text { FCM/DIM } \\
\text { Milk compone }\end{array}$ & 1.37 & 1.40 & 1.40 & 1.41 & 0.082 & 0.987 & 0.754 & 0.920 \\
\hline Fat, $\mathrm{g} / \mathrm{kg}$ & 45.6 & 45.9 & 45.5 & 47.5 & 0.779 & 0.254 & 0.121 & 0.252 \\
\hline Lactose, $\mathrm{g} / \mathrm{kg}$ & 47.8 & 47.9 & 47.7 & 48.3 & 0.600 & 0.910 & 0.682 & 0.627 \\
\hline Protein, $\mathrm{g} / \mathrm{kg}$ & $34.1^{\mathrm{c}}$ & $34.8^{b, c}$ & $37.2^{a, b}$ & $37.5^{\mathrm{a}}$ & 0.834 & 0.023 & 0.004 & 0.359 \\
\hline Casein, $\mathrm{g} / \mathrm{kg}$ & $27.1^{b}$ & $28.1^{a, b}$ & $28.7^{\mathrm{a}}$ & $29.3^{a}$ & 0.475 & 0.029 & 0.005 & 0.445 \\
\hline Urea-N, mg/kg & $105^{c}$ & $110^{\mathrm{c}}$ & $189^{b}$ & $205^{a}$ & 4.04 & $<0.0001$ & $<0.0001$ & 0.003 \\
\hline \multicolumn{9}{|c|}{ Milk components yield } \\
\hline Fat yield, kg/day & 1.09 & 1.16 & 1.22 & 1.21 & 0.059 & 0.383 & 0.151 & 0.323 \\
\hline Lactose yield, kg/day & 1.15 & 1.23 & 1.28 & 1.23 & 0.060 & 0.493 & 0.367 & 0.212 \\
\hline Protein yield, kg/day & 0.81 & 0.89 & 0.99 & 0.96 & 0.049 & 0.061 & 0.022 & 0.116 \\
\hline Casein yield, kg/day & 0.64 & 0.72 & 0.77 & 0.75 & 0.032 & 0.051 & 0.028 & 0.070 \\
\hline Urea-N yield, g/day & $2.52^{b}$ & $2.99^{b}$ & $5.05^{\mathrm{a}}$ & $5.22^{\mathrm{a}}$ & 0.233 & $<0.0001$ & $<0.0001$ & 0.007 \\
\hline
\end{tabular}

$\mathrm{SEM}=$ standard error of least square means; ${ }^{\mathrm{a}, \mathrm{b}, \mathrm{c}}$ least square means in the same row with different superscript letters differ $(p<0.05)$.

Milk fat and lactose compositions did not differ $(p>0.05)$ across dietary CP levels and averaged 46.1 and $47.9 \mathrm{~g} / \mathrm{kg}$, respectively (Table 4 ). Similarly, other previous studies [2,15] also reported no dietary $\mathrm{CP}$ level effect on milk fat composition. However, some other studies reported contrasting results. Olmos Colmenero and Broderick [17] reported a linear increase in milk fat composition when TMR diets ranging from $13.5 \%$ to $19.4 \% \mathrm{CP}$ were fed to cows. In another study, Law [27] reported a linear decrease when TMR diets ranging from 114 to $173 \mathrm{~g} \mathrm{CP} / \mathrm{kg}$ DM were fed. It should be noted, however, that the milk fat composition observed in the present study was inexplicably high. Our mean milk fat composition $(46.1 \mathrm{~g} / \mathrm{kg})$ was higher by $17.1 \%$ than the mean of $38.2 \mathrm{~g} / \mathrm{kg}$ reported by Law [27] for cows (151 to 305 DIM) fed TMR diets with a comparable concentrate-to-forage ratio as the one fed in the present study. The lack of dietary CP level effect on milk lactose composition is consistent with other studies $[2,15,27]$, where increasing dietary CP levels did not affect milk lactose composition of cows fed TMR diets with concentrate-to-forage ratios comparable to the one used in the current study.

Milk protein and casein compositions increased linearly $(p<0.05)$ with increasing dietary CP level, being highest with the 177 or 201 diets (Table 4). Similarly, Broderick [2] also reported a significant dietary $\mathrm{CP}$ level effect on milk protein composition as dietary CP was increased from $15.1 \%$ to $16.7 \%$ and then to $18.4 \%$. However, in contrast, some other studies $[15,17,27]$ observed no dietary CP level effect on milk protein composition. Milk urea-N composition was affected by dietary $\mathrm{CP}$ level in a linear $(p<0.05)$ and quadratic $(p<0.05)$ manner, being highest with the $201 \mathrm{DM}$ diet, intermediate with the 177 diet, and lowest with the 141 or 151 diets. The observed linear increase in milk urea-N composition was anticipated because milk urea-N composition is related positively to dietary protein content or intake $[18,21,28]$. Thus, milk urea-N composition has been proposed as a diagnostic of protein feeding in dairy cows $[6,28]$. Since ruminal ammonia-N increases with increasing dietary protein level $[23,24]$, an increase in milk urea- $\mathrm{N}$ concentration has to be expected when dietary protein level increases. Other studies $[14,15,17]$ also reported greater milk urea-N compositions from cows fed high-protein diets compared with those fed low-protein diets. The milk urea-N composition observed in the current study with the 201 diet $(205 \mathrm{mg} / \mathrm{kg})$ reflected protein over-feeding. Melendez [29] classified milk urea-N values beyond $17 \mathrm{mg} / \mathrm{dL}$ as high. A milk urea- $\mathrm{N}$ value of approximately $11.7 \mathrm{mg} / \mathrm{dL}$ was reported to be indicative of satisfied $\mathrm{N}$ requirements of rumen microbes for grass silage-based diets [28]. 
Milk yields of fat and lactose did not differ $(p>0.05)$ across dietary CP levels, and averaged 1.17 and $1.22 \mathrm{~kg} /$ day, respectively (Table 4). In contrast, Broderick [2] and Law [27] reported linear and/or quadratic increases in milk yield of fat as dietary $\mathrm{CP}$ level was increased. There was a tendency for higher milk yields of protein and casein ( $p=0.061$ and $p=0.051$, respectively) with the 177 or 201 diets showing linear $(p<0.05)$ responses to increasing dietary CP level. Milk yield of casein also showed a trend $(p=0.070)$ toward a quadratic response to increasing dietary $\mathrm{CP}$ level. A quadratic function predicted peak milk yield of casein to occur at a dietary CP level of $182 \mathrm{~g} / \mathrm{kg} \mathrm{DM}$. This result is in agreement with studies by Broderick [2] and Law [27] who reported linear and/or quadratic increases in milk yield of protein as dietary $\mathrm{CP}$ level was increased. Milk yield of urea-N was affected by dietary $\mathrm{CP}$ level in a linear $(p<0.05)$ and quadratic $(p<0.05)$ manner. Milk yield of urea-N was affected by dietary CP level in a linear $(p<0.05)$ and quadratic $(p<0.05)$ manner, being highest with the 177 or 201 diets. A quadratic function predicted the peak milk yield of urea- $\mathrm{N}$ to occur at a dietary $\mathrm{CP}$ level of $187 \mathrm{~g} / \mathrm{kg}$ DM. Similarly, Broderick [2] also reported a linear increase in milk yield of urea-N as dietary CP was increased from $15.1 \%$ to $18.4 \%$.

\subsection{Milk N Secretion, and N Excretion in Feces and Urine}

Urine output was affected by dietary CP level in a linear $(p<0.05)$ manner and showed a trend $(p=0.054)$ toward a quadratic response to increasing dietary $C P$ level, being highest with the 177 or 201 diets (Table 5). A quadratic function predicted peak urine output at a dietary CP level of $187 \mathrm{~g} / \mathrm{kg}$ DM. Urinary N excretion increased linearly $(p<0.05)$ with increasing dietary CP level, being highest with the 201 diet, intermediate with the 177, and lowest with the 141 or 151 diets. The proportion of $\mathrm{N}$ intake appearing as urinary $\mathrm{N}$ increased linearly $(p<0.05)$ with increasing dietary $\mathrm{CP}$ level, being highest with the 177 or 201 diets. The observed linear increases in urine output and urinary $\mathrm{N}$ excretion were anticipated because, when dietary RDP is in excess of the amount required by ruminal microorganisms, the protein is degraded to ammonia- $\mathrm{N}$, absorbed, metabolized to urea in the liver, and lost in the urine [30]. However, urinary urea excretion requires water [19,31], which inevitably leads to higher water intake and, hence, increased urine output. When dietary protein (and the subsequent $\mathrm{N}$ intake) is not in excess, ruminal ammonia- $\mathrm{N}$ production is reduced, which leads to reduced urinary $\mathrm{N}$. Others studies also reported linear increases in urine output and urinary $\mathrm{N}$ excretion with increasing dietary $\mathrm{CP}$ level $[2,17,18]$ or higher urine output and urinary $\mathrm{N}$ excretion with higher $\mathrm{CP}$ diets than lower $\mathrm{CP}$ diets [15,32].Fecal DM output tended to be higher $(p=0.051)$ with the $177 \mathrm{~g} \mathrm{CP} / \mathrm{kg}$ DM and averaged $5.73 \mathrm{~kg} / \mathrm{day}$ (Table 5 ). However, fecal $\mathrm{N}$ excretion was affected by dietary $\mathrm{CP}$ level in a quadratic $(p<0.05)$ manner (Table 5), being highest with the 177 diet, but not different among the 141, 151, and 201 diets. A quadratic function predicted peak fecal $\mathrm{N}$ excretion at a dietary CP level of $176 \mathrm{~g} / \mathrm{kg}$ DM. This result is in agreement with studies by Broderick [2], Groff and $\mathrm{Wu}$ [18], Olmos Colmenero and Broderick [17], and Recktenwald [23], who reported linear and/or quadratic increases in fecal $\mathrm{N}$ excretion as dietary $\mathrm{CP}$ level was increased. However, in contrast, some other studies $[3,14,32]$ reported no significant effect of dietary $\mathrm{CP}$ level on fecal $\mathrm{N}$ excretion. The proportion of $\mathrm{N}$ intake appearing as fecal $\mathrm{N}$ decreased linearly $(p<0.05)$ with increasing dietary $\mathrm{CP}$ level, being highest with the 141 or 151 diets, intermediate with the 177 diet, and lowest with the 201 diet.

Total manure $\mathrm{N}$ (fecal and urinary $\mathrm{N}$ ) excretion increased linearly $(p<0.05)$ with increasing dietary $\mathrm{CP}$ level, being highest with the 177 or 201 diets (Table 5). This result was anticipated because the principal driver of $\mathrm{N}$ excretion is $\mathrm{N}$ intake [33]. In addition, several researchers $[34,35]$ reported positive correlations between manure $\mathrm{N}$ excretion and dietary protein supply or $\mathrm{N}$ intake. The proportion of $\mathrm{N}$ intake appearing as manure $\mathrm{N}$ did not differ $(p>0.05)$ across dietary $\mathrm{CP}$ levels and averaged $75.2 \%$. This was not surprising because increasing dietary $\mathrm{CP}$ level shifts the $\mathrm{N}$ excretion pattern from feces to urine. In the present study, as dietary CP level was increased from 141 to 151, 177, and then to $201 \mathrm{~g} / \mathrm{kg}$ DM the proportion of $\mathrm{N}$ intake appearing as fecal $\mathrm{N}$ reduced by 8.3, 13.0, and 28.4 percentage units, respectively, while the proportion of $\mathrm{N}$ intake appearing as urinary $\mathrm{N}$ increased by $3.9,14.8$, 
and 35.3 percentage units, respectively. The average values observed in the present study for the proportion of $\mathrm{N}$ intake appearing as manure $\mathrm{N}$ are within the range reported in the literature for commercial dairy farms using TMR diets [6,7].

Table 5. Effect of dietary CP level on milk $\mathrm{N}$ secretion, and $\mathrm{N}$ excretion in feces and urine.

\begin{tabular}{|c|c|c|c|c|c|c|c|c|}
\hline & \multicolumn{4}{|c|}{ Dietary CP Content, g/kg DM } & \multirow[b]{2}{*}{ SEM } & \multicolumn{3}{|c|}{$p$-Value } \\
\hline & 141 & 151 & 177 & 201 & & Diet & Linear & Quadratic \\
\hline $\begin{array}{l}\text { Total N intake, g/day } \\
\text { Urinary excretion }\end{array}$ & $436^{\mathrm{b}}$ & $457^{\mathrm{b}}$ & $637^{a}$ & $633^{a}$ & 21.1 & $<0.0001$ & $<0.0001$ & 0.015 \\
\hline Urine output, kg/day & $18.5^{\mathrm{b}}$ & $18.6^{\mathrm{b}}$ & $24.7^{\mathrm{a}}$ & $24.1^{\mathrm{a}}$ & 0.978 & $<0.0001$ & $<0.0001$ & 0.054 \\
\hline Urinary $\mathrm{N}, \mathrm{g} /$ day & $146^{\mathrm{c}}$ & $156^{\mathrm{c}}$ & $243^{\mathrm{b}}$ & $287^{\mathrm{a}}$ & 13.8 & $<0.0001$ & $<0.0001$ & 0.652 \\
\hline $\begin{array}{c}\text { Urinary } \mathrm{N}, \% \mathrm{~N} \text { intake } \\
\text { Fecal excretion }\end{array}$ & $33.7^{b}$ & $35.0^{\mathrm{b}}$ & $38.7^{\mathrm{a}, \mathrm{b}}$ & $45.6^{\mathrm{a}}$ & 2.58 & 0.008 & 0.001 & 0.501 \\
\hline Fecal DM output, kg/day & 5.61 & 5.23 & 6.39 & 5.7 & 0.275 & 0.051 & 0.174 & 0.119 \\
\hline Fecal N, g/day & $185^{\mathrm{b}}$ & $175^{\mathrm{b}}$ & $234^{a}$ & $193^{b}$ & 11.8 & 0.016 & 0.110 & 0.023 \\
\hline Fecal N, \% N intake & $42.2^{\mathrm{a}}$ & $38.7^{\mathrm{a}, \mathrm{b}}$ & $36.7^{b}$ & $30.2^{\mathrm{c}}$ & 1.55 & $<0.0001$ & $<0.0001$ & 0.551 \\
\hline Manure N, g/day & $331^{b}$ & $332^{b}$ & $480^{\mathrm{a}}$ & $481^{\mathrm{a}}$ & 22.7 & 0.0002 & $<0.0001$ & 0.116 \\
\hline $\begin{array}{l}\text { Manure N, \% N intake } \\
\text { Milk N secretion }\end{array}$ & 75.7 & 73.7 & 75.5 & 75.8 & 3.19 & 0.948 & 0.806 & 0.836 \\
\hline Milk N ${ }^{1}, \mathrm{~g} /$ day & $127^{\mathrm{b}}$ & $138^{a, b}$ & $161^{a}$ & $149^{a, b}$ & 7.68 & 0.033 & 0.022 & 0.048 \\
\hline Milk N, \% N intake & $29.6^{a}$ & $29.9^{\mathrm{a}}$ & $25.5^{\mathrm{a}, \mathrm{b}}$ & $23.3^{b}$ & 1.62 & 0.021 & 0.003 & 0.953 \\
\hline
\end{tabular}

${ }^{1}$ Determined as milk protein yield/6.38; SEM, standard error of least square means; ${ }^{\mathrm{a}, \mathrm{b}, \mathrm{c}}$ least square means in the same row with different superscript letters differ $(p<0.05)$.

Milk N secretion was affected by dietary $\mathrm{CP}$ level in a linear $(p<0.05)$ and quadratic $(p<0.05)$ manner (Table 5). Milk N secretion first increased linearly with increasing dietary $\mathrm{CP}$ level to a peak value, with no further increase from 177 to $201 \mathrm{~g} \mathrm{CP} / \mathrm{kg}$ DM. A quadratic function predicted the peak value to occur at a dietary $\mathrm{CP}$ level of $183 \mathrm{~g} / \mathrm{kg} \mathrm{DM}$. The proportion of $\mathrm{N}$ intake appearing as milk $\mathrm{N}$ (milk N efficiency) decreased linearly $(p<0.05)$ with increasing dietary $\mathrm{CP}$ level, being lowest with the 201 diet, and highest with the 141 or 151 diets (Figure 2). Compared with the lowest CP level (141 g $\mathrm{CP} / \mathrm{kg} \mathrm{DM}$ ), the two highest $\mathrm{CP}$ levels (177 and $201 \mathrm{~g} \mathrm{CP} / \mathrm{kg} \mathrm{DM})$ resulted in 13.9 and 21.3 percentage unit reductions, respectively, in milk $\mathrm{N}$ efficiency. Similarly, other studies $[2,3,15,32]$ also reported significantly lower milk $\mathrm{N}$ efficiencies with higher-CP diets than lower-CP diets. The observed linear decrease in milk $\mathrm{N}$ efficiency with increasing dietary $\mathrm{CP}$ level was anticipated because, when RPD is in excess of the amount required by ruminal microorganisms (as was the case with the two higher-CP diets), an increased ruminal ammonia-N concentration arises [23,24], which is known to inhibit urea-N transfer to the rumen $[15,26]$, leading to increased urinary $\mathrm{N}$ excretion and, hence, reduced milk $\mathrm{N}$ efficiency. The milk $\mathrm{N}$ efficiency values observed in the current study were consistent with the data of other studies $[2,15,17,32]$ with cows fed diets ranging from $14.9 \%$ to $19.4 \% \mathrm{CP}$.

\subsection{Optimal Dietary CP Level}

Quadratic regression functions and predicted optimal dietary $\mathrm{CP}$ levels for variables that showed quadratic responses $(p \leq 0.10)$ to increasing dietary $\mathrm{CP}$ level are summarized in Table 6. The optimal dietary $\mathrm{CP}$ levels were predicted by taking first derivatives of the quadratic equations. The optimal dietary $\mathrm{CP}$ levels for milk yield and milk $\mathrm{N}$ secretion averaged $180 \mathrm{~g} \mathrm{CP} / \mathrm{kg} \mathrm{DM}$. 

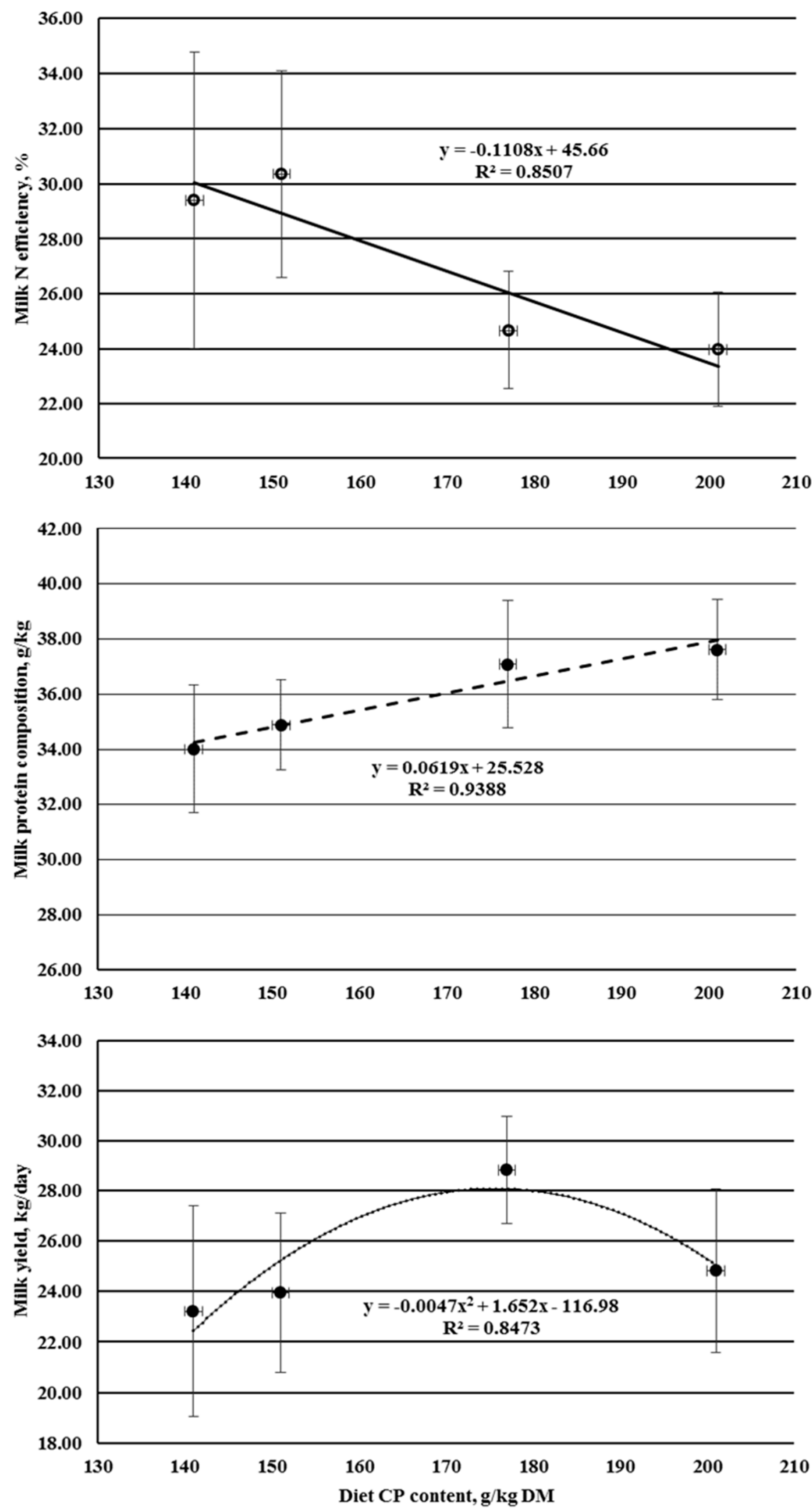

Figure 2. Increasing dietary $\mathrm{CP}$ level with milk yield, protein composition, and $\mathrm{N}$ efficiency. Bars represent the standard deviation of the means. 
Table 6. Quadratic regression equations of dietary CP level (g/kg DM).

\begin{tabular}{|c|c|c|c|c|c|c|c|c|}
\hline & \multicolumn{6}{|c|}{ Equation } & Maximum $^{1}$ & $p$-Value ${ }^{2}$ \\
\hline \multicolumn{9}{|l|}{ Intake } \\
\hline DM, kg/day & $=$ & -55.380 & + & $0.876 \mathrm{CP}$ & - & $0.00249 C \mathrm{P}^{2}$ & 176 & 0.013 \\
\hline $\mathrm{OM}, \mathrm{kg} /$ day & $=$ & -50.385 & + & $0.800 \mathrm{CP}$ & - & $0.00228 \mathrm{CP}^{2}$ & 175 & 0.013 \\
\hline $\mathrm{CP}, \mathrm{kg} /$ day & $=$ & -12.008 & + & $0.160 \mathrm{CP}$ & - & $0.00040 \mathrm{CP}^{2}$ & 200 & 0.015 \\
\hline $\mathrm{NDF}, \mathrm{kg} /$ day & $=$ & -18.823 & + & $0.318 \mathrm{CP}$ & - & $0.00092 \mathrm{CP}^{2}$ & 173 & 0.015 \\
\hline $\begin{array}{l}\text { ADF, kg/day } \\
\text { Milk yield }\end{array}$ & $=$ & -8.400 & + & $0.149 \mathrm{CP}$ & - & $0.00043 \mathrm{CP}^{2}$ & 173 & 0.021 \\
\hline Milk, kg/day & $=$ & -116.980 & + & $1.652 \mathrm{CP}$ & - & $0.00470 \mathrm{CP}^{2}$ & 176 & 0.044 \\
\hline $4 \%$ FCM, kg/day & $=$ & -133.510 & + & $1.860 \mathrm{CP}$ & - & $0.00526 \mathrm{CP}^{2}$ & 177 & 0.079 \\
\hline Milk components & & & & & & & & \\
\hline Urea-N, mg/kg & $=$ & -940.340 & + & 11.152 & - & $0.02711 C P^{2}$ & 206 & 0.003 \\
\hline Milk components yield & & & & & & & & \\
\hline Casein yield, kg/day & $=$ & -4.358 & + & $0.058 \mathrm{CP}$ & - & $0.00016 \mathrm{CP}^{2}$ & 182 & 0.070 \\
\hline $\begin{array}{l}\text { Urea-N yield, g/day } \\
\mathrm{N} \text { excretion }\end{array}$ & $=$ & -50.378 & + & $0.596 \mathrm{CP}$ & - & $0.00159 \mathrm{CP}^{2}$ & 187 & 0.007 \\
\hline Urine output, kg/day & $=$ & -97.997 & + & $1.315 \mathrm{CP}$ & - & $0.00352 \mathrm{CP}^{2}$ & 187 & 0.054 \\
\hline Fecal N, g/day & $=$ & -1290.370 & + & $17.312 \mathrm{CP}$ & - & $0.04927 \mathrm{CP}^{2}$ & 176 & 0.023 \\
\hline Milk N, g/day & $=$ & -475.590 & + & $6.927 \mathrm{CP}$ & - & $0.01893 \mathrm{CP}^{2}$ & 183 & 0.048 \\
\hline
\end{tabular}

${ }^{1}$ Determined by taking the first derivative of the quadratic equation; ${ }^{2}$ probability value of the quadratic effect of dietary CP level.

\section{Conclusions}

In this study, varying dietary CP level from 141 to 151, 177, and then to $201 \mathrm{~g} / \mathrm{kg} \mathrm{DM}$ did not affect apparent total-tract DM, NDF, and ADF digestibilities, as well as milk fat composition and yield, by lactating Holstein-Friesian cows in mid lactation (146 to 200 DIM). However, apparent total-tract $\mathrm{CP}$ digestibility, milk protein and urea- $\mathrm{N}$ compositions, urinary $\mathrm{N}$ excretion, and manure $\mathrm{N}$ excretion increased linearly, while milk $\mathrm{N}$ efficiency decreased linearly with increasing dietary $\mathrm{CP}$ level. Intake of $\mathrm{DM}$, milk yield, and fecal $\mathrm{N}$ excretion were affected by dietary $\mathrm{CP}$ level in a quadratic manner, with no further increase from 177 to $201 \mathrm{~g} \mathrm{CP} / \mathrm{kg}$ DM. Milk N secretion first increased linearly with increasing dietary CP level, peaking at a dietary level of $183 \mathrm{~g} \mathrm{CP} / \mathrm{kg} \mathrm{DM}$, and then decreased. It was clearly evident that increasing the dietary $\mathrm{CP}$ level beyond $177 \mathrm{~g} / \mathrm{kg}$ DM did not result in benefits for intake of DM and milk yield, but resulted in increased urinary $\mathrm{N}$ excretion (an environmentally labile form of $\mathrm{N}$ ), as well as decreased milk $\mathrm{N}$ secretion and, hence, reduced milk $\mathrm{N}$ efficiency. Milk $\mathrm{N}$ secretion was reduced by $7.5 \%$, while milk $\mathrm{N}$ efficiency was reduced by 8.5 percentage units as dietary $\mathrm{CP}$ was increased from 177 to $201 \mathrm{~g} / \mathrm{kg}$ DM.

Author Contributions: Conceptualization, T.Y.; methodology, C.B.K., and T.Y.; data curation, C.B.K.; writing-original draft preparation, C.B.K., and T.Y.; writing-review and editing, C.B.K., and T.Y.; project administration, T.Y.; funding acquisition, T.Y. All authors have read and agreed to the published version of the manuscript.

Funding: This research project was funded by the Department of Agriculture Environment and Rural Affairs (DAERA) in Northern Ireland.

Conflicts of Interest: The authors declare no conflict of interest.

\section{References}

1. Fadul-Pacheco, L.; Pellerin, D.; Chouinard, P.; Wattiaux, M.; Duplessis, M.; Charbonneau, É. Nitrogen efficiency of eastern Canadian dairy herds: Effect on production performance and farm profitability. J. Dairy Sci. 2017, 100, 6592-6601. [CrossRef]

2. Broderick, G.A. Effect of varying dietay protein and energy levels on the production of lactating dairy cows. J. Dairy Sci. 2003, 86, 1370-1381. [CrossRef] 
3. Agle, M.; Hristov, A.; Zaman, S.; Schneider, C.; Ndegwa, P.; Vaddella, V. The effects of ruminally degraded protein on rumen fermentation and ammonia losses from manure in dairy cows. J. Dairy Sci. 2010, 93, 1625-1637. [CrossRef]

4. Lee, C.; Hristov, A.; Dell, C.; Feyereisen, G.; Kaye, J.; Beegle, D. Effect of dietary protein concentration on ammonia and greenhouse gas emitting potential of dairy manure. J. Dairy Sci. 2012, 95, 1930-1941. [CrossRef]

5. Hristov, A.; Heyler, K.S.; Schurman, E.W.; Griswold, K.; Topper, P.A.; Hile, M.; Ishler, V.A.; Fabian-Wheeler, E.; Dinh, S. CASE STUDY: Reducing dietary protein decreased the ammonia emitting potential of manure from commercial dairy farms. Prof. Anim. Sci. 2015, 31, 68-79. [CrossRef]

6. Arriaga, H.; Pinto, M.; Calsamiglia, S.; Merino, P. Nutritional and management strategies on nitrogen and phosphorus use efficiency of lactating dairy cattle on commercial farms: An environmental perspective. J. Dairy Sci. 2009, 92, 204-215. [CrossRef]

7. Powell, J.; Jackson-Smith, D.B.; McCrory, D.F.; Saam, H.; Mariola, M. Validation of Feed and Manure Data Collected on Wisconsin Dairy Farms. J. Dairy Sci. 2006, 89, 2268-2278. [CrossRef]

8. Jonker, J.; Kohn, R.; High, J. Dairy Herd Management Practices that Impact Nitrogen Utilization Efficiency. J. Dairy Sci. 2002, 85, 1218-1226. [CrossRef]

9. Jonker, J.; Kohn, R.; Erdman, R. Using Milk Urea Nitrogen to Predict Nitrogen Excretion and Utilization Efficiency in Lactating Dairy Cows. J. Dairy Sci. 1998, 81, 2681-2692. [CrossRef]

10. Powell, J.; Gourley, C.; Rotz, C.; Weaver, D. Nitrogen use efficiency: A potential performance indicator and policy tool for dairy farms. Environ. Sci. Policy 2010, 13, 217-228. [CrossRef]

11. Huhtanen, P.; Cabezas-Garcia, E.H.; Krizsan, S.J.; Shingfield, K.J. Evaluation of between-cow variation in milk urea and rumen ammonia nitrogen concentrations and the association with nitrogen utilization and diet digestibility in lactating cows. J. Dairy Sci. 2015, 98, 3182-3196. [CrossRef] [PubMed]

12. Castro, S.B.; Phillip, L.; Lapierre, H.; Jardon, P.; Berthiaume, R. The Relative Merit of Ruminal Undegradable Protein from Soybean Meal or Soluble Fiber from Beet Pulp to Improve Nitrogen Utilization in Dairy Cows. J. Dairy Sci. 2008, 91, 3947-3957. [CrossRef] [PubMed]

13. Lee, C.; Hristov, A.; Heyler, K.; Cassidy, T.; Long, M.; Corl, B.; Karnati, S. Effects of dietary protein concentration and coconut oil supplementation on nitrogen utilization and production in dairy cows. J. Dairy Sci. 2011, 94, 5544-5557. [CrossRef] [PubMed]

14. Mutsvangwa, T.; Davies, K.; McKinnon, J.; Christensen, D. Effects of dietary crude protein and rumen-degradable protein concentrations on urea recycling, nitrogen balance, omasal nutrient flow, and milk production in dairy cows. J. Dairy Sci. 2016, 99, 6298-6310. [CrossRef]

15. Thomas, C. Feed into Milk: A New Applied Feeding System for Dairy Cows: An Advisory Manual; Nottingham University Press: Nottingham, UK, 2004.

16. Van Soest, P.; Robertson, J.; Lewis, B. Methods for Dietary Fiber, Neutral Detergent Fiber, and Nonstarch Polysaccharides in Relation to Animal Nutrition. J. Dairy Sci. 1991, 74, 3583-3597. [CrossRef]

17. Colmenero, J.J.O.; Broderick, G.A. Effect of Dietary Crude Protein Concentration on Milk Production and Nitrogen Utilization in Lactating Dairy Cows. J. Dairy Sci. 2006, 89, 1704-1712. [CrossRef]

18. Groff, E.; Wu, Z. Milk Production and Nitrogen Excretion of Dairy Cows Fed Different Amounts of Protein and Varying Proportions of Alfalfa and Corn Silage. J. Dairy Sci. 2005, 88, 3619-3632. [CrossRef]

19. Holter, J.; Byrne, J.; Schwab, C. Crude Protein for High Milk Production. J. Dairy Sci. 1982, 65, 1175-1188. [CrossRef]

20. Marini, J.C.; Van Amburgh, M. Partition of Nitrogen Excretion in Urine and the Feces of Holstein Replacement Heifers. J. Dairy Sci. 2005, 88, 1778-1784. [CrossRef]

21. Burgos, S.; Fadel, J.; Depeters, E.J. Prediction of Ammonia Emission from Dairy Cattle Manure Based on Milk Urea Nitrogen: Relation of Milk Urea Nitrogen to Urine Urea Nitrogen Excretion. J. Dairy Sci. 2007, 90, 5499-5508. [CrossRef]

22. Lapierre, H.; Berthiaume, R.; Raggio, G.; Thivierge, M.C.; Doepel, L.; Pacheco, D.; Dubreuil, P.; Lobley, G.E. The route of absorbed nitrogen into milk protein. Anim. Sci. 2005, 80, 11-22. [CrossRef]

23. Recktenwald, E.; Ross, D.; Fessenden, S.; Wall, C.; Van Amburgh, M. Urea-N recycling in lactating dairy cows fed diets with 2 different levels of dietary crude protein and starch with or without monensin. J. Dairy Sci. 2014, 97, 1611-1622. [CrossRef] [PubMed] 
24. Reynolds, C.K.; Kristensen, N.B. Nitrogen recycling through the gut and the nitrogen economy of ruminants: An asynchronous symbiosis1. J. Anim. Sci. 2008, 86, E293-E305. [CrossRef] [PubMed]

25. Sinclair, K.D.; Garnsworthy, P.C.; Mann, G.E.; Sinclair, L.A. Reducing dietary protein in dairy cow diets: Implications for nitrogen utilization, milk production, welfare and fertility. Animals 2014, 8, 262-274. [CrossRef] [PubMed]

26. Lu, Z.; Stumpff, F.; Deiner, C.; Rosendahl, J.; Braun, H.; Abdoun, K.; Aschenbach, J.R.; Martens, H. Modulation of sheep ruminal urea transport by ammonia and pH. Am. J. Physiol. Integr. Comp. Physiol. 2014, 307, R558-R570. [CrossRef] [PubMed]

27. Law, R.A.; Young, F.J.; Patterson, D.C.; Kilpatrick, D.J.; Wylie, A.R.G.; Mayne, C.S. Effect of dietary protein content on animal production and blood metabolites of dairy cows during lactation. J. Dairy Sci. 2009, 92, 1001-1012. [CrossRef]

28. Nousiainen, J.; Shingfield, K.; Huhtanen, P. Evaluation of Milk Urea Nitrogen as a Diagnostic of Protein Feeding. J. Dairy Sci. 2004, 87, 386-398. [CrossRef]

29. Melendez, P.; Donovan, A.; Hernández, J. Milk Urea Nitrogen and Infertility in Florida Holstein Cows. J. Dairy Sci. 2000, 83, 459-463. [CrossRef]

30. Bach, A.; Calsamiglia, S.; Stern, M.D. Nitrogen metabolism in the rumen. J. Dairy Sci. 2005, 88, E9-E21. [CrossRef]

31. Valadares, R.; Broderick, G.; Filho, S.V.; Clayton, M. Effect of Replacing Alfalfa Silage with High Moisture Corn on Ruminal Protein Synthesis Estimated from Excretion of Total Purine Derivatives. J. Dairy Sci. 1999, 82, 2686-2696. [CrossRef]

32. Niu, M.; Appuhamy, J.A.D.R.N.; Leytem, A.B.; Dungan, R.S.; Kebreab, E. Effect of dietary crude protein and forage contents on enteric methane emissions and nitrogen excretion from dairy cows simultaneously. Anim. Prod. Sci. 2016, 56, 312-321. [CrossRef]

33. Kebreab, E.; Strathe, A.B.; Dijkstra, J.; Mills, J.A.N.; Reynolds, C.K.; Crompton, L.A.; Yan, T.; France., J. Energy and Protein Interactions and Their Effects on Nitrogen Excretion in Dairy Cows. In Energy and Protein Metabolism and Nutrition, 1st ed.; Crovetto, G.M., Ed.; Wageningen Academic Publishers: Wageningen, The Netherlands, 2010; Volume 127, pp. 417-425.

34. Yan, T.; Frost, J.; Agnew, R.; Binnie, R.; Mayne, C. Relationships among Manure Nitrogen Output and Dietary and Animal Factors in Lactating Dairy Cows. J. Dairy Sci. 2006, 89, 3981-3991. [CrossRef]

35. Angelidis, A.; Crompton, L.; Misselbrook, T.; Yan, T.; Reynolds, C.; Stergiadis, S. Evaluation and prediction of nitrogen use efficiency and outputs in faeces and urine in beef cattle. Agric. Ecosyst. Environ. 2019, 280, 1-15. [CrossRef]

Publisher's Note: MDPI stays neutral with regard to jurisdictional claims in published maps and institutional affiliations.

(C) 2020 by the authors. Licensee MDPI, Basel, Switzerland. This article is an open access article distributed under the terms and conditions of the Creative Commons Attribution (CC BY) license (http://creativecommons.org/licenses/by/4.0/). 